\title{
Flue Gas Waste Heat and Water Recovery Organic Rankine Cycle
}

\author{
Young Min Kim, Gyu Baek Cho, Sunyoup Lee, Dong Gil Shin \\ Department of Environmental and Energy System/Korea Institute of Machinery and Materials \\ 156 Gajeongbuk-Ro, Yuseong-Gu, Deaejeon, Republic of Korea \\ ymkim@kimm.re.kr; gybcho@kimm.re.kr; sunylee@kimm.re.kr; sdk@kimm.re.kr
}

\section{Extended Abstract}

Fossil fuel-based power plants consume significant amount of water. Therefore, the power plants can cause an environmental impact and its locations are very limited by the availability of water. Water recovery from flue gas in the power plants could contribute to reduce water requirement. For example, a 600MW coal power plant releases 45 ton/min of flue gas including $7.2 \mathrm{ton} / \mathrm{min}$ of moisture [1]. Several technologies including water condensation by cooling water [1], liquid desiccant dehumidification system (LDDS) [2], and transport membrane condenser (TMC) [3] have been developed.

In this study, in order to condense the moisture in flue gas, the flue gas is firstly cooled down by a waste heat recovery (WHR) organic Rankine cycle (ORC) system and is further cooled down below dew point $\left(55^{\circ} \mathrm{C}\right)$ by a pumped heat pipe cooling loop combined with the ORC system. Two-phase cooling by the organic working fluid instead of cooling water can reduce the large surface area [4] of condensing heat exchanger for low-temperature flue gas. Furthermore, an ejector cooling system or vapor compression refrigeration system driven by the waste heat of flue gas [5], combined with the ORC system, can be used to further cool down the flue gas because it is very difficult to condense the moisture in the flue gas with a high ambient temperature.

In the case of the $600 \mathrm{MW}$ coal power plant releasing $150^{\circ} \mathrm{C}$ of flue gas, the WHR ORC system can produce about $6.7 \mathrm{MW}$ of additional power and recover $50 \%$ of water in flue gas by cooling the flue gas to $40^{\circ} \mathrm{C}$ at the evaporation temperature of $30^{\circ} \mathrm{C}$ for R134a. Furthermore, with the help of the vapor compression cooling system driven by the heated high pressure working fluid, it can recover $70 \%$ of water in flue gas by cooling the flue gas to $30^{\circ} \mathrm{C}$ at the evaporation temperature of $20^{\circ} \mathrm{C}$ for R134a. Along with the water recovery in the condensing heat exchanger, condensable particulate matter (CPM) can be separated from the flue gas for environmental friendliness [6,7].

\section{References}

[1] K. Jeong and E. K. Levy, "Analytical modelling of water condensation in condensing heat exchanger," International Journal of Heat and Mass Transfer., vol. 53, pp. 2361-68, 2010.

[2] J. H. Copen, T. B. Sullivan, and B. C. Folkedahl, "Principles of flue gas water recovery system," in Proceedings of the Power-Gen International Conference, Las Vegas NV, December 2005.

[3] D. Wang, A. Bao, W. Kunc, and W. Liss, "Coal power plant flue gas waste heat and water recovery," Applied Energy., vol. 91, pp. 341-348, 2012.

[4] R. Hannemann, J. Marsala, and M. Pitasi, "Pumped liquid multiphase cooling," in Proceedings of the ASME International Mechanical Engineering Congress and Exposition, Anaheim CA, November 2004.

[5] M. A. Redo, M. Berana, and K. Saito, "Ejector refrigeration system driven by renewable energy and waste heat," in Proceedings of the IEA Heat Pump Conference, Rotterdam, 2017.

[6] K. Jeong and E. K. Levy, "Theoretical prediction of surfuric acid condensation rates in boiler flue gas," International Journal of Heat and Mass Transfer., vol. 55, pp. 8010-19, 2012.

[7] Z. Qi, J. Li, D. Wu, W. Xie, X. Li, and C. Liu, "Particulate matter emission characteristics removal efficiencies of a low-low temperature electrostatic precipitator," Energy Fuels., vol. 31, pp. 1741-46, 2017. 